Article

\title{
Antiproliferative Phenanthrenes from Juncus tenuis: Isolation and Diversity-Oriented Semisynthetic Modification
}

\author{
Csaba Bús ${ }^{1}$, Norbert Kúsz ${ }^{1}\left(\right.$, Annamária Kincses ${ }^{2}{ }^{\oplus}$, Nikoletta Szemerédi $^{2}{ }^{(D)}$, \\ Gabriella Spengler ${ }^{2}{ }^{\circledR}$, László Bakacsy ${ }^{3}{ }^{\circledR}$, Dragica Purger ${ }^{4}$, Róbert Berkecz ${ }^{5}$, Judit Hohmann ${ }^{1,6}$, \\ Attila Hunyadi ${ }^{1, *(D)}$ and Andrea Vasas ${ }^{1, *}$ \\ 1 Department of Pharmacognosy, University of Szeged, 6720 Szeged, Hungary; bcsaba0312@gmail.com (C.B.); \\ kusznorbert@gmail.com (N.K.); hohmann.judit@szte.hu (J.H.) \\ 2 Department of Medical Microbiology and Immunobiology, University of Szeged, Dóm tér 10, \\ 6720 Szeged, Hungary; kincses.annamaria90@gmail.com (A.K.); \\ szemeredi.nikoletta@med.u-szeged.hu (N.S.); spengler.gabriella@med.u-szeged.hu (G.S.) \\ 3 Department of Plant Biology, University of Szeged, Közép Fasor 52, 6726 Szeged, Hungary; \\ bakacsy@gmail.com \\ 4 Department of Pharmacognosy, University of Pécs, Rókus u. 2, 7624 Pécs, Hungary; \\ dragica@gamma.ttk.pte.hu \\ 5 Institute of Pharmaceutical Analysis, University of Szeged, Somogyi u. 4, 6720 Szeged, Hungary; \\ berkecz.robert@pharm.u-szeged.hu \\ 6 Interdisciplinary Centre of Natural Products, University of Szeged, Eötvös u. 6, 6720 Szeged, Hungary \\ * Correspondence: hunyadi.a@pharmacognosy.hu (A.H.); vasasa@pharmacognosy.hu (A.V.); \\ Tel.: +36-62-546-451 (A.H. \& A.V.)
}

Academic Editor: Piotr Paweł Wieczorek

Received: 23 November 2020; Accepted: 16 December 2020; Published: 17 December 2020

check for updates

\begin{abstract}
The occurrence of phenanthrenes is limited in nature, with such compounds identified only in some plant families. Phenanthrenes were described to have a wide range of pharmacological activities, and numerous research programs have targeted semisynthetic derivatives of the phenanthrene skeleton. The aims of this study were the phytochemical investigation of Juncus tenuis, focusing on the isolation of phenanthrenes, and the preparation of semisynthetic derivatives of the isolated compounds. From the methanolic extract of J. tenuis, three phenanthrenes (juncusol, effusol, and 2,7-dihydroxy-1,8-dimethyl-5-vinyl-9,10-dihydrophenanthrene) were isolated. Juncusol and effusol were transformed by hypervalent iodine(III) reagent, using a diversity-oriented approach. Four racemic semisynthetic compounds possessing an alkyl-substituted $p$-quinol ring (1-4) were produced. Isolation and purification of the compounds were carried out by different chromatographic techniques, and their structures were elucidated by means of 1D and 2DNMR, and HRMS spectroscopic methods. The isolated secondary metabolites and their semisynthetic analogues were tested on seven human tumor cell lines (A2780, A2780cis, KCR, MCF-7, HeLa, HTB-26, and T47D) and on one normal cell line (MRC-5), using the MTT assay. The effusol derivative 3, substituted with two methoxy groups, showed promising antiproliferative activity on MCF-7, T47D, and A2780 cell lines with IC $_{50}$ values of $5.8,7.0$, and $8.6 \mu \mathrm{M}$, respectively.
\end{abstract}

Keywords: Juncus tenuis; phenanthrene; juncusol; effusol; semisynthetic derivatives; antiproliferative activity 


\section{Introduction}

To date, approximately 500 phenanthrenes from 59 genera of 18 families were isolated. The major sources of phenanthrenes are Orchidaceae, Juncaceae, Combretaceae, and Dioscoreaceae species $[1,2]$. The family Juncaceae includes up to 500 species belonging to seven genera (Distichia, Juncus, Luzula, Marsippospermum, Oxychloe, Patosia, and Rostkovia). Among them, Juncus is the largest one, which comprises approximately 340 species [3]. Besides flavonoids, phenanthrenes are the main bioactive constituents of the Juncaceae species [4]. To date, more than one hundred phenanthrenes have been isolated from ten Juncus species (J. acutus, J. atratus, J. compressus, J. effusus, J. gerardii, J. inflexus, J. maritimus, J. roemerianus, J. setchuensis, and J. subulatus) [5-8]. Some Juncus species are extremely rich sources of phenanthrenes; for example, from J. effusus, 58 compounds were reported in previous studies. Since various Juncus phenanthrenes are substituted with a vinyl group, such compounds are considered to be important chemotaxonomic markers of the genus [5,9].

Phenanthrenes have become the subjects of numerous pharmacological studies. Their antiproliferative, antimicrobial (antifungal, antiviral, and antibacterial), antialgal, anti-inflammatory, antioxidant, anxiolytic, and hepatoprotective activities were reported [2,10]. The presence of a quinone moiety in the molecules resulted in increased antiproliferative activity [11]. The cytotoxicity of quinones can be explained by many mechanisms, including intercalation, inhibition of DNA and RNA, by breaking of DNA strands, alteration of cell membrane functions, redox cycling that leads to the formation of reactive oxygen species (ROS), and ROS- or Michael-addition-mediated alkylation of various biochemical targets [12-14]. While quinones, in general, are considered as unfavorable to be included in screening libraries due to their tendency to behave as pan-assay interference compounds (PAINS) [15], many approved anticancer drugs have such a structure. Furthermore, the quinone and quinol moieties are not only versatile synthons to increase chemical diversity [16], but these may also serve as warheads for potential covalent inhibitors of well-defined biochemical targets $[17,18]$. Concerning further structure-activity relationships of phenanthrene derivatives, the combined presence of methyl, hydroxy, and vinyl substituents on ring $C$, a methyl and a hydroxy group on ring $\mathrm{A}$, and a single bond between C-9 and C-10 increase the antiproliferative effect of phenanthrenes [19]. Denbinobin, isolated from an orchid species (Dendrobium nobile), is the most widely investigated phenanthrene quinone. It exerts cytotoxic activity through different mechanisms, like apoptosis induction via caspase-dependent and independent pathways [20-22], inducing oxidative stress through increasing ROS levels [23], and inhibition of the topoisomerase II enzyme [24]. Moreover, 5-hydroxy-2,3-dimethoxy-1,4-phenanthrenequinone showed specific cytotoxicity against the HL-60 cell line (with an $\mathrm{IC}_{50}$ value of $4.7 \mu \mathrm{M}$ ) [25]. Another phenanthraquinone, calanquinone $\mathrm{A}$, was tested against several cancer cell lines. This compound inhibited the growth of A549 (IC $50.61 \mu \mathrm{M})$, PC-3 (IC $50.51 \mu \mathrm{M})$, DU145 (IC $501.08 \mu \mathrm{M})$, HCT-8 (IC $50.64 \mu \mathrm{M})$, MCF-7 ( $\left.\mathrm{IC}_{50} 0.10 \mu \mathrm{M}\right), \mathrm{KB}\left(\mathrm{IC}_{50} 1.02 \mu \mathrm{M}\right)$, and vincristine resistant KBVIN (IC $\left.501.43 \mu \mathrm{M}\right)$ cells, respectively [26]. The aims of our work were the isolation and structure determination of phenanthrenes from Juncus tenuis, the preparation of oxidized semisynthetic derivatives of the isolated phenanthrenes motivated by the aforementioned structural attributes of quinoidal compounds, and the characterization of the antiproliferative activity of these compounds on human adherent tumor cell lines. The value of the chosen semisynthetic approach in increasing the chemical-pharmacological diversity was previously demonstrated by our group. Starting from juncuenin B, we prepared and characterized eleven derivatives via hypervalent iodine-catalyzed oxidation. Among these differently substituted compounds bearing $p$ - or $o$-quinol rings, three showed considerable antiproliferative effects against different tumor cell lines, and their activity was enantiospecific [27].

From the dichloromethane fraction of the methanolic extract of J. tenuis, three compounds (juncusol, effusol, and 2,7-dihydroxy-1,8-dimethyl-5-vinyl-9,10-dihydrophenanthrene) were isolated. As a result of the semisynthetic processes, two juncusol derivatives $(\mathbf{1}, \mathbf{2})$ and two effusol derivatives $(3,4)$ were obtained. The structures of these compounds were elucidated by 1D and 2D NMR (Nuclear Magnetic Resonance), and MS (Mass Spectrometry) measurements. The antiproliferative 
activity of the compounds was investigated on seven human tumor cell lines (A2780, A2780cis, KCR, MCF-7, HeLa, HTB-26, and T47D) and on MRC-5 human embryonal lung fibroblasts.

\section{Results and Discussion}

\subsection{Isolation, Semisynthetic Derivatization, and Structure Determination of the Compounds}

Dried aerial parts of $J$. tenuis were ground and extracted with $\mathrm{MeOH}$, at room temperature. After concentration, the extract was dissolved in $50 \%$ aqueous $\mathrm{MeOH}$, and solvent-solvent partition was performed with $n$-hexane and $\mathrm{CH}_{2} \mathrm{Cl}_{2}$ (dichloromethane). The $\mathrm{CH}_{2} \mathrm{Cl}_{2}$ phase was separated and purified with a combination of different chromatographic methods (CC, VLC, RPC, MPLC, and HPLC) to afford three compounds.

The structure determination was carried out by extensive spectroscopic analysis, using 1D NMR $\left({ }^{1} \mathrm{H}\right.$ and JMOD) spectroscopy and a comparison of the spectral data with those published in the literature $[28,29]$. Based on the NMR spectra and the literature data, juncusol, effusol, and 2,7-dihydroxy-1,8-dimethyl-5-vinyl-9,10-dihydrophenanthrene were identified. J. tenuis is an abundant source of juncusol and effusol, as approximately $200 \mathrm{mg}(0.012 \% w / w)$ were isolated from $1.68 \mathrm{~kg}$ of dried plant material.

Juncusol was isolated previously from numerous Juncus species (J. acutus, J. effusus, J. inflexus, J. roemerianus, J. setchuensis, and J. subulatus) [9,30-34]. Similarly to juncusol, effusol is also a ubiquitous phenanthrene in Juncus species, as it was isolated from J. acutus, J. atratus, J. compressus, J. effusus, J. maritimus, J. setchuensis, and J. subulatus [6,7,30,33-36]. Moreover, 2,7-Dihydroxy-1,8-dimethyl-5-vinyl-9,10-dihydrophenanthrene was identified before from J. acutus and J. effusus $[19,28,29]$.

Four semisynthetic derivatives (1-4) were prepared from juncusol and effusol, in four transformations (I-IV), using a hypervalent iodine(III) reagent in a diversity-oriented approach (Scheme 1 and Figure 1.). While many oxidants are available for the oxidation of phenols, the use of [bis-(trifluoroacetoxy)]iodobenzene (PIFA) was a natural follow-up to our previous work on the diversity-oriented transformation of phenolic natural products. This reagent allows selective transformation of phenolic hydroxyl groups under mild conditions, and we have previously found it to be efficient in the (i) synthesis of functionalized quinol derivatives with antitumor potential [27,37], and (ii) simulation of certain biomimetic oxidative conditions [38]. The latter is because it may act not only through an aryloxyiodonium(III) intermediate forming a phenoxenium ion that undergoes a nucleophilic attack, but it can also oxidize aromatic compounds via a single-electron transfer mechanism [39,40]. In this work, PIFA was used in MeCN-MeOH (processes I and III), or MeCN-EtOH (II and IV), at room temperature, and this led to the formation of quinol-type products. Since both abovementioned reaction mechanisms orient subsequent coupling reaction steps to the ortho or para positions, these products were expectably $o$ - and/or $p$-quinol derivatives. Following the oxidation, the mixture of products was subjected to a solid-phase extraction on silica gel, to remove the remaining oxidizing agent and the oxidation side-products. The purification process was followed by MPLC and HPLC.

During the reaction processes, the mixture of products, bearing $o$ - and $p$-quinol rings and substituted by methoxy- and ethoxy groups, were formed according to the solvent used. As the result of chromatographic purifications, all compounds were obtained as diastereomeric mixtures of two racemates.

The structure determination was carried out by extensive spectroscopic analysis, using HRESIMS, and $1 \mathrm{D}$ and 2D NMR $\left({ }^{1} \mathrm{H}_{-}{ }^{1} \mathrm{H}\right.$ COSY, HSQC, and HMBC) measurements. The structures of the semisynthetic derivatives are depicted in Figure 1. 
<smiles>C=Cc1c(C)c(O)cc2c1-c1ccc(O)c(C(C)(C)C)c1CC2</smiles><smiles>C=Cc1cc(O)cc2c1-c1ccc(O)c(CC)c1CC2</smiles>

Scheme 1. Transformation of juncusol and effusol under different conditions. PIFA: [bis-(trifluoroacetoxy)]iodobenzene.

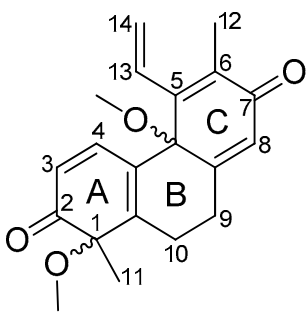

ent-1a and ent-1b<smiles>C=CC1=C(C)C(=O)C=C2CCC3=C(C=CC(=O)C3(C)OCC)C21OCC</smiles>

ent-2a and ent-2b<smiles>C=CC1=CC(=O)C=C2CCC3(C)C(=CC)C(C)(OC)C(=O)C=C3C12C</smiles>

3<smiles>C=CC1=CC(=O)C=C2CCC3=C(CC=CC3=O)C2(OCC)C1(C)OCC</smiles>

ent-4a and ent-4b

Figure 1. The structures of semisynthetic derivatives of juncusol $(\mathbf{1}, \mathbf{2})$ and effusol $(\mathbf{3}, \mathbf{4})$.

The ${ }^{1} \mathrm{H}-\mathrm{NMRspectrum}$ of $\mathbf{1 a}$ and $\mathbf{1} \mathbf{b}$ showed that these compounds are racemic diastereomers (Figures S1 and S7). Since these compounds are derived from juncusol, similar signals were found in the ${ }^{1} \mathrm{H}$-NMR spectrum: resonances of two 0 -coupled aromatic protons $\left(\delta_{\mathrm{H}} 5.96 \mathrm{dd} / 5.91 \mathrm{dd}\right.$ and $\left.6.83 \mathrm{~d} / 6.88 \mathrm{~d}\right)$, two methyls $\left(\delta_{\mathrm{H}} 1.26 \mathrm{~s} / 1.14 \mathrm{~s}\right.$ and $\left.2.15 \mathrm{~s} / 2.16 \mathrm{~s}\right)$, a vinylic system at $\delta_{\mathrm{H}} 6.89 \mathrm{dd} / 6.91 \mathrm{dd}, 6.01 \mathrm{dd} / 6.02 \mathrm{dd}$, and $5.96 \mathrm{dd} / 5.69 \mathrm{dd}\left(\mathrm{H}-13, \mathrm{H}_{2}-14\right)$, two methylene groups $\left(\delta_{\mathrm{H}} 2.89 \mathrm{~m} / 2.91 \mathrm{~m}, 2.48 \mathrm{~m} / 2.58 \mathrm{~m}\right.$ and $\delta_{\mathrm{H}}$ $3.00 \mathrm{~m} / 2.95 \mathrm{~m}, 2.79 \mathrm{ddd} / 2.95 \mathrm{~m})$, and signals of two methoxy groups $\left(\delta_{\mathrm{H}} 3.15 \mathrm{~s} / 2.92 \mathrm{~s}\right.$ and $\left.3.00 \mathrm{~s} / 3.02 \mathrm{~s}\right)$ (Table 1). The presence of two methylene signals $\left(\mathrm{H}_{2}-9\right.$ and $\left.\mathrm{H}_{2}-10\right)$ indicated this racemic pair to be 9,10-dihydrophenanthrene derivatives. In the JMOD (J-modulated spin-echo experiment) spectrum, 20 carbon signals were displayed (Table 2). In the ${ }^{1} \mathrm{H}-{ }^{1} \mathrm{H}$ COSY spectrum, correlations were observed between $\delta_{\mathrm{H}} 5.96 \mathrm{dd} / 5.91 \mathrm{dd}$ and $\delta_{\mathrm{H}} 6.83 \mathrm{~d} / 6.88 \mathrm{~d}(\mathrm{H}-3-\mathrm{H}-4)$, between $\delta_{\mathrm{H}} 2.89 \mathrm{~m} / 2.91 \mathrm{~m}, 2.48 \mathrm{~m} / 2.58 \mathrm{~m}$ and $\delta_{\mathrm{H}} 3.00 \mathrm{~m} / 2.95 \mathrm{~m}, 2.79 \mathrm{ddd}(\mathrm{H}-9-\mathrm{H}-10)$ and between $\delta_{\mathrm{H}} 6.89 \mathrm{dd} / 6.91 \mathrm{dd}$ and $\delta_{\mathrm{H}} 6.01 \mathrm{dd} / 6.02 \mathrm{dd}$, $5.96 \mathrm{dd} / 5.69 \mathrm{dd}\left(\mathrm{H}-13-\mathrm{H}_{2}-14\right)$ (Figure 2.). The locations of the methoxy groups were concluded from the $\mathrm{HMBC}$ spectra, as the proton signal at $\delta_{\mathrm{H}} 3.15 / 2.92\left(\mathrm{CH}_{3} \mathrm{O}-1\right)$ gave cross-peaks with $\delta_{\mathrm{C}} 84.7 / 82.4$ (C-1), whereas the signal at $\delta_{\mathrm{H}} 3.00 / 3.02\left(\mathrm{CH}_{3} \mathrm{O}-5 \mathrm{a}\right)$ correlated with $\delta_{\mathrm{C}} 77.5 / 76.8$ (C-5a) (Figure 2.). Thus, the $\mathrm{C}-2$ and $\mathrm{C}-7$ hydroxy groups of juncusol were oxidized to carbonyl groups $\left(\delta_{C} 202.6 / 202.9\right.$ and 184.9/184.8, respectively), and methoxy-substituted dienone moieties were formed. 
Table 1. ${ }^{1} \mathrm{H}-\mathrm{NMR}$ spectroscopic data for compounds $\mathbf{1 - 4}\left(500 \mathrm{MHz}, \mathrm{CDCl}_{3}, \delta \mathrm{ppm}\right.$, and $J$ in $\left.\mathrm{Hz}\right)$.

\begin{tabular}{|c|c|c|c|c|c|c|c|}
\hline Position & $1 \mathrm{a}$ & $1 \mathrm{~b}$ & $2 a$ & $2 b$ & 3 & $4 a$ & $4 b$ \\
\hline 3 & $5.96 \mathrm{dd}(10.3,1.1)$ & $5.91 \mathrm{dd}(10.3,1.1)$ & $5.89 \mathrm{~d}(10.2)$ & $5.94 \mathrm{~d}(10.3)$ & $6.01 \mathrm{dd}(10.3,0.9)$ & $5.93 \mathrm{~d}(10.3)$ & $5.98 \mathrm{~d}(10.3)$ \\
\hline 4 & $6.83 \mathrm{~d}(10.3)$ & $6.88 \mathrm{~d}(10.3)$ & $6.84 \mathrm{~d}(10.2)$ & 6. $80 \mathrm{~d}(10.3)$ & $6.98 \mathrm{~d}(10.3)$ & $6.96 \mathrm{~d}(10.3)$ & $6.94 \mathrm{~d}(10.3)$ \\
\hline 8 & $6.29 \mathrm{~s}$ & $6.29 \mathrm{br} \mathrm{s}$ & $6.24 \mathrm{~s}$ & $6.24 \mathrm{~s}$ & $6.28 \mathrm{~s}$ & $6.23 \mathrm{~s}$ & $6.23 \mathrm{~s}$ \\
\hline 9 & $2.89 \mathrm{~m}, 2.48 \mathrm{~m}$ & $2.91 \mathrm{~m}, 2.58 \mathrm{~m}$ & $2.87 \mathrm{~m}, 2.51, \mathrm{~m}$ & $2.87 \mathrm{~m}, 2.47 \mathrm{~m}$ & $2.89 \mathrm{~m}, 2.55 \mathrm{~m}$ & $2.57 \mathrm{~m}, 2.91 \mathrm{~m}$ & $2.87 \mathrm{~m}, 2.53 \mathrm{~m}$ \\
\hline 10 & $3.00 \mathrm{~m}, 2.79$ ddd $(17.4,8.3,1.6)$ & $2.95 \mathrm{~m}(2 \mathrm{H})$ & $2.99 \mathrm{~m}, 2.93 \mathrm{~m}$ & $2.99 \mathrm{~m}, 2.82 \mathrm{~m}$ & $2.99 \mathrm{~m}(2 \mathrm{H})$ & $2.99 \mathrm{~m}, 2.86 \mathrm{~m}$ & $2.81 \mathrm{~m}, 2.47 \mathrm{~m}$ \\
\hline 11 & $1.26 \mathrm{~s}$ & $1.14 \mathrm{~s}$ & $1.42 \mathrm{~s}$ & $1.25, \mathrm{~s}$ & $1.27 \mathrm{~s}$ & $1.42 \mathrm{~s}$ & $1.27 \mathrm{~s}$ \\
\hline 12 & $2.15 \mathrm{~s}$ & $2.16 \mathrm{~s}$ & $2.14 \mathrm{~s}$ & $2.14 \mathrm{~s}$ & & & \\
\hline 13 & 6. $89 \mathrm{dd}(17.8,10.7)$ & $6.91 \mathrm{dd}(17.8,11.9)$ & $6.90 \mathrm{dd}(17.7,11.9)$ & $6.88 \mathrm{dd}(17.7,11.8)$ & $6.64 \mathrm{dd}(17.7,11.3)$ & $6.64 \mathrm{dd}(17.7,11.3)$ & $6.64 \mathrm{dd}(17.7,11.3)$ \\
\hline 14 & $6.01 \mathrm{dd}(17.8,1.3)$ & $6.02 \mathrm{dd}(17.8,1.3)$ & $6.05 \mathrm{~d}(17.7)$ & $6.03 \mathrm{~d}(17.7)$ & 6.08 br d (17.7) & $6.10 \mathrm{~d}(17.7)$ & $6.09 \mathrm{~d}(17.7)$ \\
\hline
\end{tabular}

1a: $\mathrm{CH}_{3} \mathrm{O}-1: 3.15 \mathrm{~s} ; \mathrm{CH}_{3} \mathrm{O}-5 \mathrm{a}: 3.00 \mathrm{~s} ; \mathbf{1 b}: \mathrm{CH}_{3} \mathrm{O}-1: 2.92 \mathrm{~s} ; \mathrm{CH}_{3} \mathrm{O}-5 \mathrm{a}: 3.02 \mathrm{~s} ; 2 \mathrm{a}: \mathrm{C}_{2} \mathrm{H}_{5} \mathrm{O}-1: 3.15 \mathrm{dq}(14.1,7.0), 273 \mathrm{dq}(14.1,7.0)\left(\mathrm{CH}_{2}\right), 1.16 \mathrm{t}(7.0)\left(\mathrm{CH}_{3}\right), \mathrm{C}_{2} \mathrm{H}_{5} \mathrm{O}-5 \mathrm{a}: 3.20 \mathrm{dq}(14.3,7.0), 3.04 \mathrm{dq}$

$(14.3,7.0)\left(\mathrm{CH}_{2}\right), 1.12 \mathrm{t}(7.0)\left(\mathrm{CH}_{3}\right) ; 2 \mathbf{b}: \mathrm{C}_{2} \mathrm{H}_{5} \mathrm{O}-1: 3.37 \mathrm{dq}(14.2,7.0), 3.13 \mathrm{dq}(14.2,7.0)\left(\mathrm{CH}_{2}\right), 1.24 \mathrm{t}(7.0)\left(\mathrm{CH}_{3}\right) ; \mathrm{C}_{2} \mathrm{H}_{5} \mathrm{O}-5 \mathrm{a}: 3.20 \mathrm{dq}(14.1,7.0), 3.04 \mathrm{dq}(14.1,7.0), 1.11 \mathrm{t}(7.0), 6-\mathrm{CH}_{3}: 2.14 \mathrm{~s} ; 3:$

$\mathrm{CH}_{3} \mathrm{O}-1: 3.15 \mathrm{~s} ; \mathrm{CH}_{3} \mathrm{O}-5 \mathrm{a}: 3.06 \mathrm{~s}$; $4 \mathrm{a}: \mathrm{C}_{2} \mathrm{H}_{5} \mathrm{O}-1: 3.18 \mathrm{~m}, 2.75 \mathrm{~m}\left(\mathrm{CH}_{2}\right), 1.16 \mathrm{t}(7.0)\left(\mathrm{CH}_{3}\right) ; \mathrm{C}_{2} \mathrm{H}_{5} \mathrm{O}-5 \mathrm{a}: 3.24 \mathrm{~m}, 3.11 \mathrm{~m}\left(\mathrm{CH}_{2}\right), 1.16 \mathrm{t}(7.0)\left(\mathrm{CH}_{3}\right) ; 4 \mathbf{b}: \mathrm{C}_{2} \mathrm{H}_{5} \mathrm{O}-1: 3.38 \mathrm{~m}, 3.11 \mathrm{~m}\left(\mathrm{CH}_{2}\right), 1.24 \mathrm{t}(7.0)$

$\left(\mathrm{CH}_{3}\right) ; \mathrm{C}_{2} \mathrm{H}_{5} \mathrm{O}-5 \mathrm{a}: 3.24 \mathrm{~m}, 3.11 \mathrm{~m}\left(\mathrm{CH}_{2}\right), 1.15 \mathrm{t}(7.0)\left(\mathrm{CH}_{3}\right)$ 
Table 2. ${ }^{13} \mathrm{C}-\mathrm{NMRspectroscopic} \mathrm{data} \mathrm{for} \mathrm{compounds} \mathbf{1}-\mathbf{4}\left(125 \mathrm{MHz}, \mathrm{CDCl}_{3}\right.$, and $\left.\delta \mathrm{ppm}\right)$.

\begin{tabular}{|c|c|c|c|c|c|c|c|}
\hline 9 & $1 \mathbf{a}$ & $1 b$ & $2 a$ & $2 b$ & $3 a$ & $4 a$ & $4 b$ \\
\hline 1 & 84.7, C & $82.4, \mathrm{C}$ & $81.7, \mathrm{C}$ & $84.2, \mathrm{C}$ & $84.5, \mathrm{C}$ & $81.8, \mathrm{C}$ & $84.0, \mathrm{C}$ \\
\hline $1 \mathrm{a}$ & $157.6, \mathrm{C}$ & $160.4, \mathrm{C}$ & $160.7, \mathrm{C}$ & $158.1, \mathrm{C}$ & 157.7, C & $160.5, \mathrm{C}$ & $153.6, \mathrm{C}$ \\
\hline 2 & $202.6, \mathrm{C}$ & $202.9, \mathrm{C}$ & $203.1, \mathrm{C}$ & $202.8, C$ & 202.3, C & $202.4, C$ & $202.5, C$ \\
\hline 3 & 123.7, CH & 123.1, CH & 123.0, CH & 123.6, CH & $124.4, \mathrm{CH}$ & $123.8, \mathrm{CH}$ & 124.3, CH \\
\hline 4 & $142.2, \mathrm{CH}$ & $142.2, \mathrm{CH}$ & $142.2, \mathrm{CH}$ & $142.1, \mathrm{CH}$ & 141.1, CH & 141.1, CH & 141.1, CH \\
\hline $4 a$ & $132.4, \mathrm{C}$ & 132.6, C & $132.1, \mathrm{C}$ & $132.0, \mathrm{C}$ & $131.8, \mathrm{C}$ & $131.3, \mathrm{C}$ & $131.3, \mathrm{C}$ \\
\hline $5 a$ & $77.5, \mathrm{C}$ & $76.8, \mathrm{C}$ & $76.4, \mathrm{C}$ & $76.8, \mathrm{C}$ & $76.6, \mathrm{C}$ & $75.9, \mathrm{C}$ & $76.4, \mathrm{C}$ \\
\hline 5 & $146.1, \mathrm{C}$ & $145.9, \mathrm{C}$ & $146.6, \mathrm{C}$ & $146.7, \mathrm{C}$ & $152.7, \mathrm{C}$ & $153.2, \mathrm{C}$ & $153.3, \mathrm{C}$ \\
\hline 6 & $138.4, \mathrm{C}$ & $138.8, \mathrm{C}$ & $138.1, \mathrm{C}$ & $137.8, \mathrm{C}$ & $130.5, \mathrm{C}$ & $130.3, \mathrm{CH}$ & $130.0, \mathrm{CH}$ \\
\hline 7 & $184.6, \mathrm{C}$ & $184.8, \mathrm{C}$ & $184.8, \mathrm{C}$ & $184.9, \mathrm{C}$ & $184.9, \mathrm{C}$ & $185.1, \mathrm{C}$ & $202.5, \mathrm{C}$ \\
\hline 8 & 126.2, $\mathrm{CH}$ & $125.9, \mathrm{CH}$ & $125.5, \mathrm{CH}$ & $125.8, \mathrm{CH}$ & $126.8, \mathrm{CH}$ & 126.0, $\mathrm{CH}$ & $126.3, \mathrm{CH}$ \\
\hline $8 a$ & $160.8, \mathrm{C}$ & $160.9, \mathrm{C}$ & 161.6, C & $161.5, \mathrm{C}$ & 161.5, C & $162.3, \mathrm{C}$ & $162.2, \mathrm{C}$ \\
\hline 9 & $25.9, \mathrm{CH}_{2}$ & $25.5, \mathrm{CH}_{2}$ & $25.8, \mathrm{CH}_{2}$ & $26.2, \mathrm{CH}_{2}$ & 26.3, $\mathrm{CH}_{2}$ & $26.2, \mathrm{CH}_{2}$ & $26.5, \mathrm{CH}_{2}$ \\
\hline 10 & $24.1, \mathrm{CH}_{2}$ & $23.2, \mathrm{CH}_{2}$ & $23.2, \mathrm{CH}_{2}$ & $24.2, \mathrm{CH}_{2}$ & $25.0, \mathrm{CH}_{2}$ & $24.0, \mathrm{CH}_{2}$ & $24.9, \mathrm{CH}_{2}$ \\
\hline 11 & $25.4, \mathrm{CH}_{3}$ & $26.4, \mathrm{CH}_{3}$ & $26.4, \mathrm{CH}_{3}$ & $25.5, \mathrm{CH}_{3}$ & $25.8, \mathrm{CH}_{3}$ & $26.5, \mathrm{CH}_{3}$ & $25.9, \mathrm{CH}_{3}$ \\
\hline 12 & $11.9, \mathrm{CH}_{3}$ & $11.9, \mathrm{CH}_{3}$ & $11.8, \mathrm{CH}_{3}$ & $11.8, \mathrm{CH}_{3}$ & & & \\
\hline 13 & 132.1, CH & $132.1, \mathrm{CH}$ & $132.2, \mathrm{CH}$ & $132.3, \mathrm{CH}$ & 134.4, $\mathrm{CH}$ & $134.5, \mathrm{CH}$ & $134.5, \mathrm{CH}$ \\
\hline 14 & $125.6, \mathrm{CH}_{2}$ & $125.4, \mathrm{CH}_{2}$ & $125.3, \mathrm{CH}_{2}$ & $125.6, \mathrm{CH}_{2}$ & $123.1, \mathrm{CH}_{2}$ & $123.1, \mathrm{CH}_{2}$ & 123.0, $\mathrm{CH}_{2}$ \\
\hline
\end{tabular}

1a: $\mathrm{CH}_{3} \mathrm{O}-1$ : 55.0; $\mathrm{CH}_{3} \mathrm{O}-5 \mathrm{a}: 52.8 ; 1$ b: $\mathrm{CH}_{3} \mathrm{O}-1$ : 54.4; $\mathrm{CH}_{3} \mathrm{O}-5 \mathrm{a}: 52.9 ; 2 \mathrm{a}: \mathrm{C}_{2} \mathrm{H}_{5} \mathrm{O}-1: 62.3\left(\mathrm{CH}_{2}\right), 15.0\left(\mathrm{CH}_{3}\right) ; \mathrm{C}_{2} \mathrm{H}_{5} \mathrm{O}-5 \mathrm{a}$ : $60.7\left(\mathrm{CH}_{2}\right), 15.0\left(\mathrm{CH}_{3}\right) ; 2$ b: $\mathrm{C}_{2} \mathrm{H}_{5} \mathrm{O}-1: 63.0\left(\mathrm{CH}_{2}\right), 15.8\left(\mathrm{CH}_{3}\right), \mathrm{C}_{2} \mathrm{H}_{5} \mathrm{O}-5 \mathrm{a}: 60.7\left(\mathrm{CH}_{2}\right), 15.1\left(\mathrm{CH}_{3}\right) ; 3: \mathrm{CH}_{3} \mathrm{O}-1$ : $55.0\left(\mathrm{CH}_{3}\right), \mathrm{CH}_{3} \mathrm{O}-5 \mathrm{a}: 52.9\left(\mathrm{CH}_{3}\right) ; 4 \mathrm{a}: \mathrm{C}_{2} \mathrm{H}_{5} \mathrm{O}-1: 62.4\left(\mathrm{CH}_{2}\right), 15.7\left(\mathrm{CH}_{3}\right), \mathrm{C}_{2} \mathrm{H}_{5} \mathrm{O}-5 \mathrm{a}: 61.0\left(\mathrm{CH}_{2}\right), 15.2\left(\mathrm{CH}_{3}\right) ; 4 \mathbf{b}$ : $\mathrm{C}_{2} \mathrm{H}_{5} \mathrm{O}-1: 63.0\left(\mathrm{CH}_{2}\right), 15.8\left(\mathrm{CH}_{3}\right), \mathrm{C}_{2} \mathrm{H}_{5} \mathrm{O}-5 \mathrm{a}: 61.0\left(\mathrm{CH}_{2}\right), 15.2\left(\mathrm{CH}_{3}\right)$.

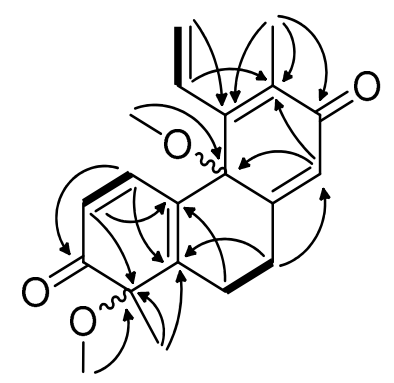

Figure 2. Diagnostic COSY $(-)$ and $\operatorname{HMBC}(\mathrm{H} \rightarrow \mathrm{C})$ correlations of compounds $\mathbf{1 a}$ and $\mathbf{1} \mathbf{b}$.

All of the above evidence confirmed the 2D structures of compounds $\mathbf{1 a}$ and $\mathbf{1} \mathbf{b}$.

Compounds $\mathbf{2} \mathbf{a}$ and $\mathbf{2} \mathbf{b}$ were also obtained as racemic diastereomers, originated from juncusol. The difference between compounds $\mathbf{1 a}$ and $\mathbf{1} \mathbf{b}$ and compounds $\mathbf{2} \mathbf{a}$ and $\mathbf{2} \mathbf{b}$ involved the replacement of the C-1 and C-5a methoxy groups with ethoxy substituents (Tables 1 and 2). Similar to $\mathbf{1 a}$ and $\mathbf{1 b}$, differences were found between the ${ }^{13} \mathrm{C}-\mathrm{NMR}$ chemical shifts of C-1 and adjacent carbon C-1a in $2 \mathbf{a}$ and $\mathbf{2 b}$, which indicated the opposite stereochemistry in chiral center C-1 in these compounds.

In the case of compound 3, a derivative of effusol, the signals of two 0 -coupled aromatic protons $\left(\delta_{\mathrm{H}} 6.01 \mathrm{dd}\right.$ and $6.98 \mathrm{~d}, \mathrm{H}-3$ and $\left.\mathrm{H}-4\right)$, two aromatic protons as a singlet (6.62 s and $6.28 \mathrm{~s} ; \mathrm{H}-6$ and $\left.\mathrm{H}-8\right)$, one methyl $\left(\delta_{\mathrm{H}} 1.27 \mathrm{~s}\right)$, a vinyl group $\left(\delta_{\mathrm{H}} 6.64 \mathrm{dd}, 6.08 \mathrm{dd}\right.$, and $\left.5.63 \mathrm{~d}, \mathrm{H}-13, \mathrm{H}_{2}-14\right)$, two methylene groups $\left(2.89 \mathrm{~m}, 2.55 \mathrm{~m}\right.$ and $\delta_{\mathrm{H}} 2.99 \mathrm{~m}, 2.77 \mathrm{ddd}, \mathrm{H}_{2}-9$ and $\left.\mathrm{H}_{2}-10\right)$, and two methoxy groups $\left(\delta_{\mathrm{H}} 3.15 \mathrm{~s}\right.$ and $3.06 \mathrm{~s}$ ) were detected in the ${ }^{1} \mathrm{H}-\mathrm{NMRspectrum}$ (Table 1). The differences between effusol and compound 3 involved the oxidation of the phenolic hydroxy groups at C-2 and C-7 to carbonyl moieties $\left(\delta_{c} 202.3\right.$ and 184.9 , respectively), and the addition of methoxy groups at C-1 and C-5a (Table 2). Although compound $\mathbf{3}$ could not be separated into racemic pairs like $\mathbf{2 a}$ and $\mathbf{2 b}$ or $\mathbf{4 a}$ and $\mathbf{4 b}$, the presence of four stereoisomers can be supposed with regard to the similar reaction process. 
Compounds $4 \mathbf{a}$ and $\mathbf{4 b}$ differ from compound 3 in the presence of ethoxy side chains $\left(\delta_{\mathrm{H}} 3.18 \mathrm{~m}\right.$, $2.75 \mathrm{~m}\left(\mathrm{CH}_{2}\right), 1.16 \mathrm{t}\left(\mathrm{CH}_{3}\right)$, and $\left.3.24 \mathrm{~m}, 3.11 \mathrm{~m}\left(\mathrm{CH}_{2}\right), 1.16 \mathrm{t}\left(\mathrm{CH}_{3}\right)\right)$ at $\mathrm{C}-1$ and $\mathrm{C}-5 \mathrm{a}$ in case of $4 \mathrm{a}$, and $\left(\delta_{\mathrm{H}} 3.38 \mathrm{~m}, 3.11 \mathrm{~m}\left(\mathrm{CH}_{2}\right), 1.24 \mathrm{t}\left(\mathrm{CH}_{3}\right)\right.$, and $\left.3.24 \mathrm{~m}, 3.11 \mathrm{~m}\left(\mathrm{CH}_{2}\right), 1.15 \mathrm{t}\left(\mathrm{CH}_{3}\right)\right)$ at the same positions in $4 \mathrm{~b}$, as it was deduced from the relevant HMBC interactions. Similar to compound 3, oxidation at C-2 $\left(\delta_{C} 202.2\right)$ and C-7 $\left(\delta_{C} 185.1\right)$ to carbonyl groups was observed. The main difference between $4 \mathbf{a}$ and $\mathbf{4 b}$, detected in the ${ }^{13} \mathrm{C}$-NMRspectra, was the distinct chemical shifts of C-1 (4a: $\delta_{C} 81.8$ and 4b: $\left.\delta_{C} 84.0\right)$ and $C-1 \mathrm{a}\left(4 \mathrm{a}: \delta_{C} 160.5\right.$ and $\left.4 \mathrm{~b}: \delta_{C} 153.6\right)$, suggesting that the two compounds have the opposite stereochemistry in chiral center C-1.

\subsection{Antiproliferative Activity of the Isolated Phenanthrenes}

The antiproliferative effects of the isolated natural phenanthrenes and the semisynthetic products $(\mathbf{1 b}, \mathbf{2 a}, \mathbf{2 b}, \mathbf{3}, \mathbf{4 a}$, and $\mathbf{4 b})$ were investigated by a standard MTT method on human breast (MCF-7, KCR, T47D, and HTB-26), cervical (HeLa), and ovarian (A2780 and A2780cis) cancer cells, and on MRC-5 (human embryonic lung fibroblast) cell lines. Previously, juncusol and effusol were described as having promising antiproliferative activity $\left(\mathrm{IC}_{50}\right.$ values $0.95 \mu \mathrm{M}$ for juncusol, and $3.68 \mu \mathrm{M}$ for effusol on $\mathrm{HeLa}$ cells) $[7,41]$. Juncusol was found to be nontoxic on normal skin fibroblasts CCD966SK, even at higher concentrations, but increased the number of cells in the G2/M and subG1 cell cycle phase even at lower concentrations. Moreover, juncusol caused a significant and concentration-dependent increase in caspase-3 activity, and also decreased tubulin polymerization at $200 \mu \mathrm{M}$ [41].

In our investigations, among the natural phenanthrenes, 2,7-dihydroxy-1,8-dimethyl-5-vinyl9,10-dihydrophenanthrene was the most active on all tested cell lines, with the exception of HeLa (Table 3). The only difference between juncusol and effusol is the presence of a methyl group at C-6 in juncusol. Juncusol and effusol possessed significant antiproliferative activity on HeLa cells ( $\mathrm{IC}_{50}$ values $0.5 \mu \mathrm{M}$ for juncusol, and $2.3 \mu \mathrm{M}$ for effusol, respectively). Compound 3 was found to be the most promising semisynthetic component with substantial antiproliferative effects against all tested cell lines, except for KCR, which was comparable to that of the positive control, cisplatin. Unfortunately, 3 had antiproliferative activity $\left(\mathrm{IC}_{50}=12.2 \mu \mathrm{M}\right)$ against the non-tumoral MRC-5 cells. This represents a ca. 2.1-fold selectivity against MCF-7 cells, which greatly over-performs the anticancer drug cisplatin that showed an opposite selectivity and was 2.3-fold more cytotoxic on MRC-5 cells (Table 3). Compounds $\mathbf{4 a}$ and $\mathbf{4 b}$ showed marked antiproliferative activity against MCF-7 cells ( $\mathrm{IC}_{50}$ values $11.7 \mu \mathrm{M}$ for $4 \mathbf{a}$ and $10.2 \mu \mathrm{M}$ for $4 \mathbf{b}$, respectively). In the case of 2,7-dihydroxy-1,8-dimethyl-5-vinyl-9,10-dihydrophenanthrene, IC $_{50}$ value $12.9 \mu \mathrm{M}$ was detected on MCF-7 cells. In case of effusol derivatives, the semisynthetic compounds had higher antiproliferative activities than that of the parent compound on all cell lines except on HeLa. None of the juncusol derivatives exceeded the antiproliferative effects of the parent compound. Although compounds $\mathbf{1 b}$ and 2a did not show an antiproliferative effect against normal (MRC-5) cells at tested concentrations, they possessed very weak activity against the investigated tumor cell lines. Comparing the data of effusol and juncusol derivatives, it can be stated that the presence of a methyl group at C-6 in the semisynthetic compounds resulted in a decrease of the toxic effect.

Juncuenin B, a natural phenanthrene isolated from Juncus inflexus, differs from juncusol in only the position of substituents (hydroxy at C-6, methyl at C-7, and vinyl at C-8) on ring C. In our previous investigation, semisynthetic derivatives of juncuenin B were prepared [27]. Some of these compounds contain the same structural elements ( $o$ - and $p$-quinoidal structure; methoxy- and ethoxy-substitution) as juncusol derivatives produced in this experiment. In that case, one of the joining methoxy or ethoxy groups connects at C-8a instead of C-5a. In the antiproliferative assay, these compounds showed higher activity; therefore, besides the connecting position of alkyl chains, the position of hydroxy, methoxy, and vinyl groups on ring $\mathrm{C}$ also has an important effect on the antiproliferative activity. 
Table 3. $\mathrm{IC}_{50}$ values of the compounds.

\begin{tabular}{ccccccccc}
\hline \multirow{2}{*}{\begin{tabular}{c} 
Compound \\
\cline { 2 - 8 }
\end{tabular}} & $\mathbf{9 2 7 8 0}$ & A2780cis & KCR & MCF-7 & HeLa & HTB-26 & T47D & MRC-5 \\
\hline $\begin{array}{c}\text { 2,7-dihydroxy- 1,8-dimethyl } \\
\text {-5-vinyl- }\end{array}$ & $22.3 \pm 2.7$ & $16.9 \pm 4.7$ & $24.2 \pm 2.1$ & $12.9 \pm 0.2$ & $24.7 \pm 0.3$ & $22.8 \pm 0.2$ & $14.2 \pm 1.1$ & $18.9 \pm 4.0$ \\
$\begin{array}{c}\text { 9,10-dihydrophenanthrene } \\
\text { juncusol }\end{array}$ & $23.8 \pm 1.3$ & $37.1 \pm 2.8$ & $35.8 \pm 1.7$ & $37.1 \pm 1.1$ & $0.5 \pm 0.0$ & $41.7 \pm 3.5$ & $25.0 \pm 0.4$ & $40.9 \pm 2.0$ \\
effusol & $33.1 \pm 3.1$ & $30.4 \pm 0.4$ & $39.3 \pm 1.6$ & $48.6 \pm 3.4$ & $2.3 \pm 0.7$ & $57.0 \pm 2.7$ & $24.6 \pm 1.9$ & $60.1 \pm 5.1$ \\
1b & $80.3 \pm 3.0$ & $88.2 \pm 3.1$ & $>100$ & $52.1 \pm 4.8$ & $>100$ & $74.3 \pm 3.6$ & $36.5 \pm 1.0$ & $>100$ \\
2a & $66.0 \pm 4.4$ & $62.9 \pm 1.7$ & $>100$ & $80.5 \pm 3.5$ & $94.7 \pm 3.4$ & $94.3 \pm 2.0$ & $56.3 \pm 3.4$ & $>100$ \\
2b & $39.4 \pm 3.1$ & $38.0 \pm 4.6$ & $44.2 \pm 2.6$ & $41.0 \pm 0.9$ & $61.9 \pm 0.3$ & $45.8 \pm 3.2$ & $30.3 \pm 2.5$ & $57.7 \pm 0.3$ \\
$\mathbf{3}$ & $8.6 \pm 0.5$ & $10.9 \pm 2.2$ & $18.9 \pm 1.4$ & $5.8 \pm 0.2$ & $12.9 \pm 0.4$ & $10.9 \pm 0.9$ & $7.0 \pm 1.0$ & $12.2 \pm 0.2$ \\
4a & $25.2 \pm 1.8$ & $22.5 \pm 0.2$ & $23.5 \pm 0.8$ & $11.7 \pm 0.7$ & $24.4 \pm 0.8$ & $16.1 \pm 0.2$ & $11.6 \pm 0.3$ & $14.3 \pm 0.5$ \\
4b & $22.0 \pm 2.0$ & $22.1 \pm 1.6$ & $29.4 \pm 0.9$ & $10.2 \pm 0.1$ & $35.0 \pm 1.5$ & $20.1 \pm 1.1$ & $14.2 \pm 0.6$ & $23.4 \pm 1.3$ \\
Cisplatin & $3.6 \pm 0.3$ & $7.3 \pm 0.2$ & $6.7 \pm 0.4$ & $1.4 \pm 1.1$ & $2.3 \pm 0.1$ & $20.1 \pm 2.3$ & $5.9 \pm 0.1$ & $0.6 \pm 0.0$ \\
DMSO & $>1$ & $>1$ & $>1$ & $0.8 \pm 0.1$ & $>1$ & $>1$ & $0.8 \pm 0.1$ & $>1$ \\
\hline
\end{tabular}

Determinations were performed by MTT assay, by treating the cells with compounds (100-0.19 $\mu \mathrm{M})$ for $72 \mathrm{~h}$. Data are based on two independent experiments.

\section{Materials and Methods}

\subsection{General}

NMR spectra were recorded in methanol- $d_{4}$ and $\mathrm{CDCl}_{3}$, on a Bruker Avance DRX 500 spectrometer (Bruker Biospin GmbH, Rheinstetten, Germany), at $500 \mathrm{MHz}\left({ }^{1} \mathrm{H}\right)$ and $125 \mathrm{MHz}\left({ }^{13} \mathrm{C}\right)$. The signals of the deuterated solvents were taken as references. The chemical shift values $(\delta)$ are given in ppm, and coupling constants are in $\mathrm{Hz}$. Two-dimensional experiments were performed with standard Bruker software. In the ${ }^{1} \mathrm{H}-{ }^{1} \mathrm{H}$ COSY, HSQC, and HMBC experiments, gradient-enhanced versions were applied. The HRMS spectra were acquired on a Thermo Scientific Q-Exactive Plus Orbitrap mass spectrometer (Thermo Fisher Scientific Inc., Budapest, Hungary) equipped with ESI ion source in positive ionization mode. The data were acquired and processed with the MassLynx software (Waters Corporation, Budapest, Hungary).

In the reaction processes, [bis(trifluoroacetoxy)iodo]benzene (PIFA) was used as oxidizing agent (Sigma-Aldrich, Stockholm, Sweden). The progress of reactions and the efficacy of separation were monitored by TLC on Kieselgel $60 \mathrm{~F}_{254}$ silica plates obtained from Merck (Merck, Darmstadt, Germany) and examined under UV light, at 254 and $366 \mathrm{~nm}$. Solid phase extraction (SPE) was carried out on silica gel (Kieselgel $60 \mathrm{GF}_{254}, 15 \mu \mathrm{m}$, Merck). Flash chromatography was performed by a Combi Flash $\mathrm{Rf}^{+}$Lumen instrument (Teledyne Isco). Normal phase vacuum liquid chromatography (VLC) was carried out on silica gel (Kieselgel $60 \mathrm{GF}_{254}, 15 \mu \mathrm{m}$, Merck). Rotation planar chromatography (RPC) was carried out by a Chromatotron instrument (Model 8924, Harrison Research, Palo Alto, CA, USA). All solvents used for MPLC, VLC, and RPC were of at least analytical grade (VWR Ltd., Szeged, Hungary). The isolated compounds, reaction mixtures, and processed fractions were investigated by HPLC, on a Waters instrument equipped with a Waters 2998 PDA detector, with an Agilent Eclipse

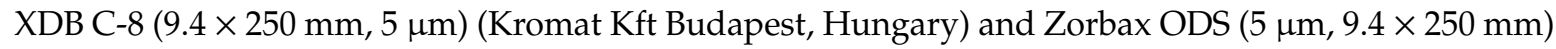
columns. $\mathrm{MeCN}-\mathrm{H}_{2} \mathrm{O}$ solvent system was used as eluent. The data were acquired and processed with the Empower software (Waters Corporation, Budapest, Hungary)

\subsection{Plant Material}

Aerial parts of Juncus tenuis Willd. were collected during the flowering period in the Botanical Garden of the University of Szeged, in June 2019. The plant material was identified by László Bakacsy (Department of Plant Biology, University of Szeged, 6726 Szeged, Hungary) and Dragica Purger (Department of Pharmacognosy, University of Pécs, 7624 Pécs, Hungary). A voucher specimen (No. 889) was deposited at the Herbarium of the Department of Pharmacognosy, University of Szeged, Szeged, Hungary. 


\subsection{Extraction and Isolation}

The air-dried aerial parts of Juncus tenuis $(1.68 \mathrm{~kg}$ ) were ground and percolated with $\mathrm{MeOH}$ (50 L), at room temperature. The crude $\mathrm{MeOH}$ extract was concentrated under reduced pressure (130.0 g); the residue was dissolved in 50\% $\mathrm{MeOH}$ and subjected to solvent-solvent partitioning with $n$-hexane $(1.5 \mathrm{~L})$ and $\mathrm{CH}_{2} \mathrm{Cl}_{2}(3 \mathrm{~L})$, respectively. After evaporation, the $\mathrm{CH}_{2} \mathrm{Cl}_{2}$ phase (22.5 g) was chromatographed by VLC, on silica gel, with a gradient system of cyclohexane-EtOAc-MeOH (from 98:2:0 to 5:5:1 (1000 mL/eluent); volume of each fractions was $100 \mathrm{~mL}$ ), to yield 3 major fractions (I-III).

Fraction I (650 mg) was separated by flash chromatography, on normal-phase silica gel with n-hexane-EtOAc gradient (linear gradient from 96:4 to 5:95) solvent system, to obtain 2 subfractions (the volume of the collected fractions was $25 \mathrm{~mL}$ ). Subfraction 1/2 was re-chromatographed on reversed-phase flash chromatography, with $\mathrm{H}_{2} \mathrm{O}-\mathrm{MeOH}$ gradient (linear gradient from 8:2 to 0:1) elution, and juncusol (176 mg) and effusol (207 mg) were obtained. Fraction III (270 mg) was further chromatographed by RPC, on silica gel, using $n$-hexane-acetone gradient system (from 9:1 to $0: 1$, volume of the collected fractions was $15 \mathrm{~mL}$ ), to obtain 2 subfractions. Subfraction III/2 was purified by RP-HPLC, applying a Zorbax ODS (5 $\mu \mathrm{m}, 9.4 \times 250 \mathrm{~mm})$ column and $\mathrm{MeOH}-\mathrm{H}_{2} \mathrm{O}$ gradient system (linear gradient from 25:75 to 94:6) as eluent (flow rate $3.0 \mathrm{~mL} / \mathrm{min}$ ), and 2,7-dihydroxy-1,8-dimethyl-5-vinyl-9,10-dihydrophenanthrene $\left(t_{\mathrm{R}}=24.3 \mathrm{~min}, 4.5 \mathrm{mg}\right)$ was isolated.

\subsection{Synthesis and Purification Process}

In each reaction process, $50 \mathrm{mg}$ of starting material (juncusol in reaction processes I and II, and effusol in III and IV) was dissolved at a concentration of $1 \mathrm{mg} / \mathrm{mL}$, in the corresponding solvent (MeCN-MeOH 9:1 in reaction processes I and III, and in MeCN-EtOH 9:1 in II and IV), and stirred with 2 equivalents of [bis-(trifluoroacetoxy)]iodobenzene (PIFA), for $30 \mathrm{~min}$, at room temperature. After evaporating the solvent under reduced pressure, SPE on silica gel was applied to absorb the remaining oxidizing agent and the possibly decomposed compounds.

Reaction mixture I was fractionated by MPLC with $n$-hexane-EtOAc gradient solvent system, to obtain 2 fractions (I/1-2). From fraction $\mathrm{I} / 2$, compounds $\mathbf{1 a}$ and $\mathbf{1 b}$ (5.3 $\mathrm{mg}$ both) were isolated by using an Agilent Eclipse XDB C-8 $(9.4 \times 250 \mathrm{~mm}, 5 \mu \mathrm{m})$ column and $\mathrm{MeCN}_{-} \mathrm{H}_{2} \mathrm{O}(1: 1)$ as mobile phase (flow rate $3 \mathrm{~mL} / \mathrm{min}$ ). Reaction mixture II was fractionated by MPLC with $n$-hexane-EtOAc gradient solvent system, to obtain 2 fractions (II/1-2). Fraction II/1 was further purified by RP-HPLC, to gain compounds $\mathbf{2 a}$ and $\mathbf{2 b}\left(t_{\mathrm{R}}=15.3\right.$ and $17.3 \mathrm{~min}, 1.6 \mathrm{mg}$ both), using an Agilent Eclipse XDB C-8 $(9.4 \times 250 \mathrm{~mm}, 5 \mu \mathrm{m})$ column and $\mathrm{MeCN}-\mathrm{H}_{2} \mathrm{O}(1: 1)$ as mobile phase (flow rate $\left.3 \mathrm{~mL} / \mathrm{min}\right)$. Reaction mixture III was fractionated by MPLC with a gradient solvent system of $n$-hexane-EtOAc, to obtain two fractions (III/1-2). From fraction III/2, compound 3 (4.3 mg) was isolated. Finally, reaction mixture IV was fractionated by MPLC with an $n$-hexane-EtOAc gradient system, to afford 4 fractions (IV/1-4). From fraction IV/1 compounds $4 \mathbf{a}$ and $\mathbf{4 b}$ (1.4 $\mathrm{mg}$ both) were isolated by RP-HPLC, using an Agilent Eclipse XDB C-8 $(9.4 \times 250 \mathrm{~mm}, 5 \mu \mathrm{m})$ column and $\mathrm{MeCN}-\mathrm{H}_{2} \mathrm{O}(6: 4)$ as eluent $\left(t_{\mathrm{R}}=23.0\right.$ and $25.3 \mathrm{~min}$, respectively $)$.

\subsubsection{Compound ent-1a}

Light brown solid; ${ }^{1} \mathrm{H}$ and ${ }^{13} \mathrm{C}$-NMRdata, see Tables 1 and 2; HRESIMS m/z 349.1412 [M + Na] ${ }^{+}$ (calcd for $\mathrm{C}_{20} \mathrm{H}_{22} \mathrm{O}_{4} \mathrm{Na}, 349.1416$ ).

\subsubsection{Compound ent-1b}

Light brown solid; ${ }^{1} \mathrm{H}$ and ${ }^{13} \mathrm{C}-\mathrm{NMRdata}$, see Tables 1 and 2 ; HRESIMS $m / z$ 349.1412 [M + Na] ${ }^{+}$ (calcd for $\mathrm{C}_{20} \mathrm{H}_{22} \mathrm{O}_{4} \mathrm{Na}$, 349.1416). 


\subsubsection{Compound ent-2a}

Pale yellow solid; ${ }^{1} \mathrm{H}$ and ${ }^{13} \mathrm{C}-\mathrm{NMR}$ data, see Tables 1 and 2; HRESIMS $m / z 355.1900[\mathrm{M}+\mathrm{H}]^{+}$ (calcd for $\mathrm{C}_{22} \mathrm{H}_{26} \mathrm{O}_{4}, 355.1904$ ).

\subsubsection{Compound ent-2b}

Pale yellow solid; ${ }^{1} \mathrm{H}$ and ${ }^{13} \mathrm{C}-\mathrm{NMR}$ data, see Tables 1 and 2; HRESIMS $m / z 355.1900[\mathrm{M}+\mathrm{H}]^{+}$ (calcd for $\mathrm{C}_{22} \mathrm{H}_{26} \mathrm{O}_{4}, 355.1904$ ).

\subsubsection{Compound 3}

Pale yellow solid; ${ }^{1} \mathrm{H}$ and ${ }^{13} \mathrm{C}-\mathrm{NMR}$ data, see Tables 1 and 2 ; HRESIMS $m / z 313.1434[\mathrm{M}+\mathrm{H}]^{+}$ (calcd for $\mathrm{C}_{19} \mathrm{H}_{20} \mathrm{O}_{4}, 313.1434$ ).

\subsubsection{Compound ent-4a}

Pale yellow solid, ${ }^{1} \mathrm{H}$ and ${ }^{13} \mathrm{C}-\mathrm{NMR}$ data, see Tables 1 and 2 ; HRESIMS $m / z 341.1746[\mathrm{M}+\mathrm{H}]{ }^{+}$ (calcd for $\mathrm{C}_{21} \mathrm{H}_{24} \mathrm{O}_{4}, 341.1747$ ).

\subsubsection{Compound ent-4b}

Pale yellow solid, ${ }^{1} \mathrm{H}$ and ${ }^{13} \mathrm{C}-\mathrm{NMR}$ data, see Tables 1 and 2 ; HRESIMS $m / z 363.1568[\mathrm{M}+\mathrm{Na}]^{+}$ (calcd for $\mathrm{C}_{21} \mathrm{H}_{24} \mathrm{O}_{4} \mathrm{Na}, 363.1572$ ).

\subsection{Antiproliferative Assay}

\subsubsection{Cell Lines}

Breast cancer cell line MCF-7 (ATCC ${ }^{\circledR}$ HTB-22) and the drug-resistant subline of the human breast cancer MCF-7 (ECACC 86012803; KCR) were purchased from LGC Promochem (Teddington, UK). Both cell lines were cultured in Eagle's Minimal Essential Medium (EMEM, containing $4.5 \mathrm{~g} / \mathrm{L}$ glucose) supplemented with a non-essential amino acid mixture, a selection of vitamins, and $10 \%$ heat-inactivated fetal bovine serum. In every third passage, $0.56 \mu \mathrm{g} / \mathrm{mL}$ doxorubicin was added to the medium, in order to maintain the ABCB1 (P-glycoprotein) expression in KCR cells. A2780 human ovarian cancer cell line (ECACC, European Collection of Authentical Cell Culture, Sigma Cat.no. 93112519) was purchased from Merck KGaA (Darmstadt, Germany). The cisplatin-resistant human ovarian cancer cell line A2780cis (ECACC European Collection of Authentical Cell Culture, Sigma Cat.no. 93112517) was purchased from Merck KGaA (Darmstadt, Germany). The human ovarian cancer cell lines were cultured in RPMI 1640 medium supplemented with $10 \%$ heat-inactivated fetal bovine serum. The RPMI 1640 medium of the cisplatin resistant cell line A2780 was supplemented with $1 \mu \mathrm{M}$ cisplatin. HeLa (ATCC ${ }^{\circledR}$ CCL-2 ${ }^{\mathrm{TM}}$ ) human cervix carcinoma cell line was purchased from LGC Promochem (Teddington, UK). The cells were cultured in Eagle's Minimal Essential Medium (EMEM, containing $4.5 \mathrm{~g} / \mathrm{L}$ glucose) supplemented with a non-essential amino acid mixture, a selection of vitamins, and $10 \%$ heat-inactivated fetal bovine serum. MRC-5 human embryonal lung fibroblast cell line (ATCC ${ }^{\circledR}$ CCL-171) was purchased from LGC Promochem, Teddington, UK. The cell line was cultured in Eagle's Minimal Essential Medium (EMEM, containing $4.5 \mathrm{~g} / \mathrm{L}$ glucose) supplemented with a non-essential amino acid mixture, a selection of vitamins, and $10 \%$ heat-inactivated fetal bovine serum. HTB-26 breast adenocarcinoma cell line was purchased from LGC Promochem, Teddington, UK. The cell line was cultured in RPMI 1640 medium supplemented with 10\% heat-inactivated fetal bovine serum. T-47D (ATCC ${ }^{\circledR}$ HTB-133 ${ }^{\mathrm{TM}}$ ) ductal carcinoma cell line was purchased from LGC Promochem, Teddington, UK. The cells were cultured in RPMI 1640 medium supplemented with 10\% heat-inactivated fetal bovine serum, $2 \mathrm{mM}$ L-glutamine, $1 \mathrm{mM}$ Na-pyruvate, and $100 \mathrm{mM}$ Hepes. All of the cells were incubated at $37^{\circ} \mathrm{C}$, in a $5 \% \mathrm{CO}_{2}$ and $95 \%$ air atmosphere. 


\subsubsection{Antiproliferative Assay}

The antiproliferative effect of the compounds was determined on human breast (MCF-7, KCR, T47D, and HTB-26), cervical (HeLa), and ovarian (A2780 and A2780cis) cancer cells, and on MRC-5 (human embryonic lung fibroblast) cell lines. The adherent cells were cultured in 96-well flat-bottomed microtiter plates, using EMEM supplemented with 10\% heat-inactivated fetal bovine serum or RPMI 1640 supplemented with $10 \%$ heat-inactivated fetal bovine serum, respectively. The density of the cells was adjusted to $6 \times 10^{3}$ cells in $100 \mu \mathrm{L}$ per well, the cells were seeded for $24 \mathrm{~h}$ at $37{ }^{\circ} \mathrm{C}$, with $5 \% \mathrm{CO}_{2}$, and then the medium was removed from the plates, and fresh medium (100 $\mu \mathrm{L}$ per well) was added to the cells. The effects of increasing concentrations of compounds on cell proliferation were tested in 96-well flat-bottomed microtiter plates. The compounds were diluted in the appropriate medium; the dilutions of compounds were performed in separate plates and then added to the cells. The starting concentration of the compounds was $100 \mu \mathrm{M}$, and two-fold serial dilution was performed (concentration range: $100-0.19 \mu \mathrm{M}$ ). The culture plates were incubated at $37^{\circ} \mathrm{C}$ for $72 \mathrm{~h}$; at the end of the incubation period, $20 \mu \mathrm{L}$ of MTT (thiazolyl blue tetrazolium bromide, Sigma) solution (from a stock solution of $5 \mathrm{mg} / \mathrm{mL}$ ) was added to each well. After incubation at $37^{\circ} \mathrm{C}$ for $4 \mathrm{~h}, 100 \mu \mathrm{L}$ of sodium dodecyl sulfate (SDS) (Sigma) solution (10\% in $0.01 \mathrm{M} \mathrm{HCI}$ ) was added to each well, and the plates were further incubated, at $37^{\circ} \mathrm{C}$, overnight. Cell growth was determined by measuring the optical density (OD) at 540/630 nm, with a Multiscan EX ELISA reader (Thermo Labsystems, Cheshire, WA, USA). Mean IC 50 values were obtained by best-fitting the dose-dependent inhibition curves in GraphPadPrism5 program (GraphPad Software version 5.00 for Windows, San Diego, CA, USA) from four parallel experiments for each cell line.

Inhibition of the cell growth was determined according to the formula below:

$$
\text { Inhibition } \%=100-\left[\frac{\text { OD sample-OD medium control }}{\text { OD cell control-OD medium control }}\right] \times 100
$$

Results are expressed in terms of $\mathrm{IC}_{50}$, defined as the inhibitory dose that reduces the proliferation of the cells exposed to the tested compounds by $50 \%$ [42].

\section{Conclusions}

From the methanolic extract of J. tenuis, three phenanthrenes, namely juncusol, effusol, and 2,7-dihydroxy-1,8-dimethyl-5-vinyl-9,10-dihydrophenanthrene, were isolated. All of them were isolated for the first time from the plant. Oxidation of juncusol and effusol with hypervalent iodine(III) reagent in $\mathrm{CH}_{3} \mathrm{CN}$-alcohol media resulted in the identification of phenanthrene derivatives substituted with methoxy and ethoxy groups at C-1 and C-5a. The semisynthetic derivatives contain substituted $o$ - and $p$-quinol rings. The semisynthetic derivatives are reported here for the first time. The substitution and position of the substituents on ring $C$ significantly affect the antiproliferative activity of the compounds.

Supplementary Materials: Supplementary materials are available online, Figures S1-S42.

Author Contributions: L.B. and D.P. identified and collected the plant material; C.B. performed the extraction and isolation and semisynthetic derivatization; N.K., R.B. and J.H. performed the spectral analysis and structure determination; A.K., N.S. and G.S. performed the antiproliferative assay; A.H. and A.V. conceived of and designed the experiments; C.B. and A.V. wrote the manuscript. All authors have read and agreed to the published version of the manuscript.

Funding: Financial support for this research was provided by the Economic Development and Innovation Operative Program GINOP-2.3.2-15-2016-00012, TKP2020-2020 FIKP program, and the UNKP-20-4-I New National Excellence Program of the Ministry of Human Capacities, and the National Research, Development and Innovation Office, Hungary (NKFIH; K128963).

Conflicts of Interest: The authors declare no conflict of interest. The founding sponsors had no role in the design of the study; in the collection, analyses, or interpretation of data; in the writing of the manuscript; or in the decision to publish the results. 


\section{References}

1. Kovács, A.; Vasas, A.; Hohmann, J. Natural phenanthrenes and their biological activity. Phytochemistry 2008, 69, 1084-1110. [CrossRef] [PubMed]

2. Tóth, B.; Hohmann, J.; Vasas, A. Phenanthrenes: A promising group of plant secondary metabolites. J. Nat. Prod. 2018, 81, 661-678.

3. Snogerup, S. A revision of Juncus subgen. Juncus (Juncaceae). Willdenowia 1993, 23, $23-73$.

4. El-Shamy, A.S.I.; Abdel-Razek, A.F.; Nassar, M.I. Phytochemical review of Juncus, L. genus (Fam. Juncaceae). Arab. J. Chem. 2015, 8, 614-623. [CrossRef]

5. Bús, C.; Tóth, B.; Stefkó, D.; Hohmann, J.; Vasas, A. Family Juncaceae: Promising source of biologically active natural phenanthrenes. Phytochem. Rev. 2018, 17, 833-851. [CrossRef]

6. Stefkó, D.; Kúsz, N.; Csorba, A.; Jakab, G.; Bérdi, P.; Zupkó, I.; Hohmann, J.; Vasas, A. Phenanthrenes from Juncus atratus with antiproliferative activity. Tetrahedron 2019, 75, 116-120. [CrossRef]

7. Bús, C.; Kúsz, N.; Jakab, G.; Tahei, S.A.S.; Zupkó, I.; Endrész, V.; Bogdanov, A.; Burián, K.; Csupor-Löffler, B.; Hohmann, J.; et al. Phenanthrenes from Juncus compressus Jacq. with promising antiproliferative and anti-HSV-2 activities. Molecules 2018, 23, 2085. [CrossRef]

8. Stefkó, D.; Kúsz, N.; Barta, A.; Kele, Z.; Bakacsy, L.; Szepesi, A.; Fazakas, C.; Wilhelm, I.; Krizbai, I.A.; Hohmann, J.; et al. Gerardiins A-L and structurally related phenanthrenes from the halophyte plant Juncus gerardii and their cytotoxicity against triple-negative breast cancer cells. J. Nat. Prod. 2020, 83, 3058-3068. [CrossRef]

9. Tóth, B.; Liktor-Busa, E.; Kúsz, N.; Szappanos, Á.; Mándi, A.; Kurtán, T.; Urbán, E.; Hohmann, J.; Chang, F.R.; Vasas, A. Phenanthrenes from Juncus inflexus with antimicrobial activity against methicillin-resistant Staphylococcus aureus. J. Nat. Prod. 2016, 79, 2814-2823. [CrossRef]

10. Ma, W.; Liu, F.; Ding, Y.Y.; Zhang, Y.; Li, N. Four new phenanthrenoid dimers from Juncus effusus L. with cytotoxic and anti-inflammatory activities. Fitoterapia 2015, 105, 83-88. [CrossRef]

11. Sánchez-Duffhues, G.; Calzado, M.A.; de Vinuesa, A.G.; Appendino, G.; Fiebich, B.L.; Loock, U.; Lefarth-Risse, A.; Krohn, K.; Muñoz, E. Denbinobin inhibits nuclear factor-кB and induces apoptosis via reactive oxygen species generation in human leukemic cells. Biochem. Pharmacol. 2009, 77, 1401-1409. [CrossRef] [PubMed]

12. Powis, G. The Toxicity of Anticancer Drugs; Pergamon Press: Oxford, UK, 1991; p. 106.

13. Gant, T.W.; Rao, D.N.R.; Mason, R.P.; Cohen, G.M. Redox cycling and sulphydryl arylation; their relative importance in the mechanism of quinone cytotoxicity to isolated hepatocytes. Chem. Biol. Interact. 1988, 65, 157. [CrossRef]

14. Bolton, J.L.; Dunlap, T. Formation and biological targets of quinones: Cytotoxic versus cytoprotective effects. Chem. Res. Toxicol. 2017, 30, 13-37. [CrossRef] [PubMed]

15. Baell, J.B.; Holloway, G.A. New substructure filters for removal of pan assay interference compounds (PAINS) from screening libraries and for their exclusion in bioassays. J. Med. Chem. 2010, 53, 2719-2740. [CrossRef] [PubMed]

16. Chandra, G.; Patel, S. Molecular complexity from aromatics: Recent advances in the chemistry of para-quinol and masked para-quinone monoketal. Chem. Sel. 2020, 5, 12885-12909. [CrossRef]

17. Baillie, T.A. Targeted covalent inhibitors for drug design. Angew. Chem. Int. Ed. 2016, 55, 2-17. [CrossRef]

18. Boström, J.; Brown, D.G.; Young, R.J.; Keserü, G.M. Expanding the medicinal chemistry synthetic toolbox. Nat. Rev. Drug Discov. 2018, 17, 709-727. [CrossRef]

19. Ma, W.; Zhang, Y.; Ding, Y.Y.; Feng, L.; Ning, L. Cytotoxic and anti-inflammatory activities of phenanthrenes from the medullae of Juncus effusus L. Arch. Pharm. Res. 2016, 39, 154-160. [CrossRef]

20. Yang, K.C.; Uen, Y.H.; Suk, F.M.; Liang, Y.C.; Wang, Y.J.; Ho, Y.S.; Li, I.H.; Lin, S.Y. Molecular mechanisms of denbinobin-induced anti-tumorigenesis effect in colon cancer cells. World, J. Gastroenterol. 2005, 11, 3040-3045. [CrossRef]

21. Kuo, C.T.; Hsu, M.J.; Chen, B.C.; Chen, C.C.; Teng, C.M.; Pan, S.L.; Lin, C.H. Denbinobin induces apoptosis in human lung adenocarcinoma cells via Akt inactivation, Bad activation, and mitochondrial dysfunction. Toxicol. Lett. 2008, 177, 48-58. [CrossRef] 
22. Song, J.I.; Kang, Y.J.; Yong, H.Y.; Kim, Y.C.; Moon, A. Denbinobin, a phenanthrene from Dendrobium nobile, inhibits invasion and induces apoptosis in SNU-484 human gastric cancer cells. Oncol. Rep. 2012, 27, 813-818. [PubMed]

23. Kuo, C.T.; Chen, B.C.; Yu, C.C.; Weng, C.M.; Hsu, M.J.; Chen, C.C.; Chen, M.C.; Teng, C.M.; Pan, S.L.; Bien, M.Y.; et al. Apoptosis signal-regulating kinase 1 mediates denbinobin-induced apoptosis in human lung adenocarcinoma cells. J. Biomed. Sci. 2009, 16, 1-15. [CrossRef] [PubMed]

24. Lee, C.L.; Lin, Y.T.; Chang, F.R.; Chen, G.Y.; Backlund, A.; Yang, J.C.; Chen, S.L.; Wu, Y.C. Synthesis and biological evaluatio of phenanthrenes as cytotoxic agents with pharmacophore modeling and ChemGPS-NP prediction as topo II inhibitors. PLoS ONE 2012, 7, e37897.

25. Masuda, Y.; Suzuki, R.; Sakagami, H.; Umemura, N.; Shirataki, Y. Novel cytotoxic phenanthrenequinone from Odontioda Marie Noel 'Velano'. Chem. Pharm. Bull. 2012, 60, 1216-1219. [CrossRef] [PubMed]

26. Lee, C.L.; Chang, F.R.; Yen, M.H.; Yu, D.; Liu, Y.N.; Bastow, K.F.; Morris-Natschke, S.L.; Wu, Y.C.; Lee, K.H. Cytotoxic phenanthrenequinones and 9,10-dihydrophenanthrenes from Calanthe arisanensis. J. Nat. Prod. 2009, 72, 210-213. [CrossRef]

27. Bús, C.; Kulmány, Á.; Kúsz, N.; Gonda, T.; Zupkó, I.; Mándi, A.; Kurtán, T.; Tóth, B.; Hohmann, J.; Hunyadi, A.; et al. Oxidized juncuenin B analogues with increased antiproliferative activity on human adherent cell lines: Semisynthesis and biological evaluation. J. Nat. Prod. 2020, 83, 3250-3261. [CrossRef]

28. DellaGreca, M.; Fiorentino, A.; Isidori, M.; Lavorgna, M.; Monaco, P.; Previtera, L.; Zarrelli, A. Phenanthrenoids from the wetland Juncus acutus. Phytochemistry 2002, 60, 633-638. [CrossRef]

29. DellaGreca, M.; Fiorentino, A.; Mangoni, L.; Molinaro, A.; Monaco, P.; Previtera, L. 9,10-dihydrophenanthrene metabolites from Juncus effusus. L. Tetrahedron Lett. 1992, 33, 5257-5260.

30. Behery, F.A.A.; Naeem, Z.E.M.; Maatooq, G.T.; Amer, M.M.A.; Wen, Z.H.; Sheu, J.H.; Ahmed, A.F. Phenanthrenoids from Juncus acutus L., new natural lipopolysaccharide-inducible nitric oxide synthase inhibitors. Chem. Pharm. Bull. 2009, 55, 1264-1266. [CrossRef]

31. DellaGreca, M.; Monaco, P.; Previtera, L.; Zarrelli, A. Minor bioactive dihydrophenanthrenes from Juncus effuses. J. Nat. Prod. 1997, 60, 1265-1268. [CrossRef]

32. Miles, D.H.; Bhattacharyya, J.; Mody, N.V.; Atwood, J.L.; Black, S.; Hedin, P.A. The structure of juncusol. A novel cytotoxic dihydrophenanthrene from the Estuarine marsh plant Juncus roemerianus. J. Am. Chem. Soc. 1977, 99, 618-620. [CrossRef] [PubMed]

33. Wang, X.Y.; Ke, C.Q.; Tang, C.P.; Yuan, D.; Ye, Y. 9,10-Dihydrophenanthrenes and phenanthrenes from Juncus setchuensis. J. Nat. Prod. 2009, 72, 1209-1212. [CrossRef] [PubMed]

34. Abdel-Razik, A.F.; Elshamy, A.S.I.; Nassar, M.I.; El-Kousy, S.M.; Hamdy, H. Chemical constituents and hepatoprotective activity of Juncus subulatus. Rev. Lationoam. Quim. 2009, 37, 70-84.

35. Wang, Y.G.; Wang, Y.L.; Zhai, H.F.; Liao, Y.J.; Zhang, B.; Huang, J.M. Phenanthrenes from Juncus effusus with anxiolytic and sedative activities. Nat. Prod. Res. 2012, 26, 1234-1239. [CrossRef] [PubMed]

36. Sahli, R.; Rivière, C.; Siah, A.; Smaoui, A.; Samaillie, J.; Hennebelle, T.; Roumy, V.; Ksouri, R.; Halama, P.; Sahpaz, S. Biocontrol activity of effusol from the extremophile plant, Juncus maritimus, against the wheat pathogen Zymoseptoria tritici. Environ. Sci. Pollut. Res. Int. 2018, 25, 29775-29783. [CrossRef] [PubMed]

37. Dankó, B.; Tóth, S.; Martins, A.; Vágvölgyi, M.; Kúsz, N.; Molnár, J.; Chang, F.R.; Wu, Y.C.; Szakács, G.; Hunyadi, A. Synthesis and SAR study of anticancer protoflavone derivatives: Investigation of cytotoxicity and interaction with ABCB1 and ABCG2 multidrug efflux transporters. ChemMedChem 2017, 12, 850-859. [CrossRef]

38. Fási, L.; Di Meo, F.; Kuo, C.Y.; Buric, S.S.; Martins, A.; Kúsz, N.; Béni, Z.; Dékány, M.; Balogh, G.T.; Pesic, M.; et al. Antioxidant-inspired drug discovery: Antitumor metabolite is formed in situ from a hydroxycinnamic acid derivative upon free-radical scavenging. J. Med. Chem. 2019, 62, 657-1668. [CrossRef]

39. Kürti, L.; Herczegh, P.; Visy, J.; Simonyi, M.; Antus, S.; Pelter, A. New insights into the mechanism of phenolic oxidation with phenyliodonium (III) reagents. J. Chem. Soc. Perkin Trans. 1999, 1, 379-380. [CrossRef]

40. Kita, Y.; Tohma, H.; Hatanaka, K.; Takada, T.; Fujita, S.; Mitoh, S.; Sakurai, H.; Oka, S. Hypervalent iodine-induced nucleophilic substitution of para-substituted phenol ethers. Generation of cation radicals as reactive intermediates. J. Am. Chem. Soc. 1994, 116, 3684-3691. [CrossRef]

41. Kuo, C.Y.; Schelz, Z.; Tóth, B.; Vasas, A.; Ocsovszki, I.; Chang, F.R.; Hohmann, J.; Zupkó, I.; Wang, H.C. Investigation of natural phenanthrenes and the antiproliferative potential of juncusol in cervical cancer cell lines. Phytomedicine 2019, 58, 152770. [CrossRef] 
42. Bacher, F.; Wittmann, C.; Nové, M.; Spengler, G.; Marć, M.A.; Enyedy, E.A.; Darvasiová, D.; Rapta, P.; Reinere, T.; Arion, V.B. Novel latonduine derived proligands and their copper(II) complexes show cytotoxicity in the nanomolar range in human colon adenocarcinoma cells and in vitro cancer selectivity. Dalton Trans. 2019, 48, 10464. [CrossRef] [PubMed]

Sample Availability: Samples of the compounds are not available from the authors.

Publisher's Note: MDPI stays neutral with regard to jurisdictional claims in published maps and institutional affiliations.

(C) 2020 by the authors. Licensee MDPI, Basel, Switzerland. This article is an open access article distributed under the terms and conditions of the Creative Commons Attribution (CC BY) license (http://creativecommons.org/licenses/by/4.0/). 